\title{
Density-dependent sea urchin grazing: differential removal of species, changes in community composition and alternative community states
}

\author{
Jeffrey T. Wright ${ }^{1,3, *}$, Symon A. Dworjanyn ${ }^{1,4}$, Cary N. $\operatorname{Rogers}^{1}{ }^{1}$ Peter D. Steinberg ${ }^{1,2}$, \\ Jane E. Williamson ${ }^{1,5}$, Alistair G. B. Poore ${ }^{1}$ \\ ${ }^{1}$ School of Biological, Earth and Environmental Sciences, and ${ }^{2}$ Centre for Marine Biofouling and Bio-Innovation, \\ The University of New South Wales, New South Wales 2052, Australia \\ ${ }^{3}$ Present address: Institute of Conservation Biology and Department of Biological Sciences, University of Wollongong, \\ New South Wales 2522, Australia
}

${ }^{4}$ Present address: NSW Department of Primary Industries, Port Stephens Fisheries Centre, New South Wales 2315, Australia

${ }^{5}$ Present address: Department of Biological Sciences, Macquarie University, New South Wales 2109, Australia

\begin{abstract}
The grazing activity of consumers causes shifts between alternative states in a variety of terrestrial and marine ecosystems. One of the best examples of a consumer-driven shift occurs on temperate marine reefs, where grazing by high densities of sea urchins results in a shift from a foliose algal- to a crustose algal-dominated state. In this study, we focussed on 2 largely untested but important issues during the transition from a foliose algal- to a crustose algal-dominated state: (1) whether sea urchins impact foliose algal community composition by differentially removing species and (2) whether any impacts of grazing vary with 2 different densities of aggregating sea urchins. We tracked the movement of a high-density front of the sea urchin Heliocidaris erythrogramma and then performed experimental manipulations of $H$. erythrogramma at 2 unusually high but naturally occurring densities. Non-metric multidimensional scaling (nMDS) followed by analysis of similarities (ANOSIM) showed differences in the foliose algal community composition, and therefore differential removal of species, between permanent plots before and during grazing (surveys), and between grazed and ungrazed plots (experiment). Of the 6 abundant foliose algae, 2 had relatively low survivorship (Amphiroa anceps and Zonaria diesingiana), while 2 had relatively high survivorship (Delisea pulchra and Corallina officinalis) when grazed by high densities of sea urchins. Grazing by different densities of $H$. erythrogramma resulted in differences in the foliose algal community composition and for the chemically-defended D. pulchra there appeared to be a threshold sea urchin density required before its removal. Our results show that an intermediate community state composed of grazer-resistant foliose algae and crustose algae can occur, which may have important consequences for community composition.
\end{abstract}

KEY WORDS: Sea urchins · Differential grazing $\cdot$ Community composition $\cdot$ Alternative community states · Density-dependent effects · Heliocidaris erythrogramma · Herbivory · Australia

\section{INTRODUCTION}

Many ecosystems can exist in alternative community states and a variety of factors trigger switches between states in different systems (May 1977, Scheffer et al. 2001). For example, in combination with other factors, variation in consumer activity causes switches between states in both terrestrial, aquatic and marine systems (Dublin et al. 1990, Van de Koppel et al. 1997, Duffy \& Hay 2001, Bertness et al. 2004, Schrage \& Downing 2004). On tropical marine reefs, a reduction in the abundance, or the total removal of herbivorous 
fishes and sea urchins, results in a switch from a coraldominated to a foliose algal-dominated state (Hughes 1994). Similarly, in temperate marine systems, the occurrence of high-density aggregations of grazing sea urchins results in a switch from a foliose algaldominated to a crustose algal-dominated state (Dean et al. 1984, Ebeling et al. 1985, Fletcher 1987, Andrew 1993, Leinaas \& Christie 1996, Benedetti-Cecchi et al. 1998, Shears \& Babcock 2002, Konar \& Estes 2003, Gagnon et al. 2004). Thus, the intense level of herbivory that occurs in many marine systems (Hay \& Steinberg 1992, Duffy \& Hay 2001) has direct implications for the community state, and marine communities often exist as a mosaic of alternative community states that are a direct result of spatial and/or temporal variation in grazing intensity (e.g. Ebeling et al. 1985, Konar \& Estes 2003).

The creation of these alternative community states by marine herbivores also directly influences algal community composition. Crustose coralline algae (hereafter crustose algae) are more abundant where the intensity of grazing is high (Duffy \& Hay 2001). Additionally, some tropical species of foliose, fleshy and turfing algae (hereafter foliose algae) suffer relatively low loss to grazing fishes and are more abundant in habitats with high grazing intensity (Hay et al. 1983, Hay 1984, Lewis 1986, Thacker et al. 2001). Generally, species of foliose algae that survive in habitats with intense grazing pressure in the tropics have spatial or temporal refuges, or have chemical and/or structural defences that deter grazing (see reviews by Duffy \& Hay 2001, Paul et al. 2001). Unpalatable and/or chemically defended tropical cyanobacteria (Thacker et al. 2001) and sponges (Pawlik et al. 1995) are also more abundant in habitats with high grazing intensity.

In contrast to evidence from the tropics, the extent to which different species of temperate foliose algae persist under intense sea urchin grazing pressure is not well understood. Although many temperate foliose algae possess chemical defences and sea urchins often have feeding preferences that can be explained by those compounds (Hay et al. 1987, Wright et al. 2004), it is generally assumed that because grazing by aggregations of sea urchins is so intense, they remove foliose algae non-selectively during the switch from a foliose algal- to crustose algal-dominated state. There are probably 2 reasons for this assumption. First, the focus of most studies of urchin-dominated communities has been on following the recovery of the foliose algal community after removal of sea urchins from barrens habitats (e.g. Fletcher 1987, Andrew \& Underwood 1993, Leinaas \& Christie 1996, Benedetti-Cecchi et al. 1998, Shears \& Babcock 2002); relatively few studies have added sea urchins to foliose algal beds and followed the transition from a foliose algal- to a crustose algal-dominated community (although see Andrew 1993, Konar \& Estes 2003, Hill et al. 2003). Second, studies examining the effects of sea urchin grazing often pool algal species into functional groups (e.g. turfing, filamentous, foliose, articulated corallines; Ebeling et al. 1985, Benedetti-Cecchi et al. 1998, Konar \& Estes 2003) rather than examining the response of individual species. In addition, to our knowledge, only 1 study has examined how variation in the density of sea urchins (i.e. variable 'high' densities) affects the transition to a crustose algal-dominated state (Hill et al. 2003). For these reasons, it is unclear whether aggregations of temperate sea urchins remove algae selectively or whether different sea urchin densities matter during the transition to the crustose algaldominated state.

Heliocidaris erythrogramma (Valenciennes, 1846) is a common subtidal sea urchin in temperate southeastern Australia (Keesing 2001). It is usually found at densities $<10 \mathrm{~m}^{-2}$ (Wright et al. 2000) but has been described in aggregations exceeding 100 urchins $\mathrm{m}^{-2}$ (Keesing 2001, Wright \& Steinberg 2001). In 1995, a high-density aggregation of $H$. erythrogramma was observed moving in a front through an algal community at a site near Sydney, Australia (Wright et al. 2000). This aggregation persisted at this site for $>3 \mathrm{yr}$ (J. T. Wright pers. obs.) although the front only took 3 to $4 \mathrm{mo}$ to move through fixed quadrats (Wright \& Steinberg 2001).

In this study, we examined the impacts of these highdensities of $H$. erythrogramma on the algal community and asked 2 main questions: (1) Is there differential removal of foliose algal species during grazing? (2) Do the impacts of grazing (i.e. differential removal of foliose algal species and changes in community composition) vary between 2 different densities of aggregating sea urchins? If the assumption of nondifferential removal holds, all species of foliose algae will be removed at the same rate during grazing and no discernable difference in foliose algal composition will occur during the transition from a foliose algal- to a crustose algal-dominated state. Similarly, if the impacts of $H$. erythrogramma are density-independent, then the hierarchy of species removal and foliose algal community composition should not differ with urchin density. To examine these questions, we first established permanent transects perpendicular to the front of $H$. erythrogramma, followed their movement, and measured changes in algal community composition during the switch from a foliose algal- to a crustose algal-dominated state. These permanent transects allowed us to determine whether there were differences in the foliose algal community composition before, during, and after grazing by high sea urchin densities. Following these surveys, we transplanted 
H. erythrogramma at 2 'high' densities into a foliose algal-dominated community to determine their effect on the rate and hierarchy of foliose algal removal, and foliose algal community composition during the transition to a crustose algal-dominated state.

\section{MATERIALS AND METHODS}

Study site. This study was undertaken on a subtidal reef approximately 3 to $4 \mathrm{~m}$ below MLLW at Bare Island, near Sydney, Australia (3359' 32" S, $\left.151^{\circ} 13^{\prime} 50^{\prime} \mathrm{E}\right)$. The macroalgal community at Bare Island is diverse with the most abundant species being the foliose red alga Delisea pulchra, various brown algae (Ecklonia radiata, Sargassum vestitum, Sargassum linearifolium, Zonaria diesingiana and Dilophus marginatus), coralline turfing red algae (Corallina officinalis and Amphiroa anceps) and crustose red algae (Sporolithon durum, Lithamnion spp.). Several sea urchins and large gastropods occur at Bare Island (Andrew 1991, Wright et al. 2000, Williamson et al. 2004) but Heliocidaris erythrogramma is the most abundant and grazing by high-density aggregations of this urchin (>80 urchins $\mathrm{m}^{-2}$ ) resulted in lower recruitment and higher mortality of $D$. pulchra compared to sites without $H$. erythrogramma (Wright \& Steinberg 2001).

Sea urchin movement and changes in the algal community. In December 1996, 5 permanent transects each $15 \mathrm{~m}$ in length were established perpendicular to the high-density front of Heliocidaris erythrogramma, and marked at each end with eyebolts. Ten $0.5 \mathrm{~m} \times 0.5 \mathrm{~m}$ quadrats were placed at $1.5 \mathrm{~m}$ intervals along each transect. Each transect started with 3 to 4 quadrats within the foliose algal habitat (where high densities of sea urchins had yet to invade) and passed through the sea urchin front into the crustose algal-dominated habitat. These permanent quadrats were sampled on December 19, 1996, February 21, 1997, April 24, 1997 , June 24, 1997 and September 2, 1997. In each quadrat, the number of $H$. erythrogramma was counted and the cover of each foliose algal species, crustose algae (all species pooled) and bare substratum was measured using a 100-point grid where each point of the grid that fell over algae or bare rock was recorded.

Although initially all transects were established so that they contained a similar number of quadrats positioned before, during and after the sea urchin front had passed, the front did not move perpendicular to the transects, but instead crossed at an angle $\left(\sim 45^{\circ}\right)$ to them. By the end of the surveys, the sea urchin front was diffuse and scattered. Consequently, quadrats in the same spatial position on different transects did not always have the same grazing history. In order to com- pare changes in algal composition as a function of sea urchin grazing, we defined all quadrats at each sampling time into 1 of 3 categories: 'before', 'during' or 'after' the sea urchin front had passed using a quantitative definition based on Heliocidaris erythrogramma density. At Bare Island, densities of $H$. erythrogramma ranged from 10 to $20 \mathrm{~m}^{-2}$ before the front to $>100 \mathrm{~m}^{-2}$ at the front before declining to $<40 \mathrm{~m}^{-2}$ after the front had passed (Wright \& Steinberg 2001). We defined the 'before' category as $<40$ urchins $\mathrm{m}^{-2}$; the 'during' category as $>40$ urchins $\mathrm{m}^{-2}$; and the 'after' category as $<40$ urchins $\mathrm{m}^{-2}$. Because we were following urchin movement, with the exception of the initial sampling time (December 19, 1996), we could easily separate quadrats with $<40$ urchins $\mathrm{m}^{-2}$ into 'before' and 'after' categories. For December 19, 1996, we designated quadrats with $<40$ urchins $\mathrm{m}^{-2}$ as 'before' and 'after' based on their position in the transect relative to the direction of urchin movement.

We examined how the algal community composition changed as the front of Heliocidaris erythrogramma moved through it using non-metric multidimensional scaling (nMDS). Similarity matrices were constructed using the Bray-Curtis coefficient and square root-transformed data (Clarke \& Warwick 1994). Algal composition was contrasted between the 'before', 'during' and 'after' categories by analysis of similarities (ANOSIM; Clarke \& Warwick 1994). Analyses were run twice: first, including all foliose algal species and crustose algae and second, with crustose algae excluded. The latter contrast allowed an examination of changes in foliose algal species composition only during the formation of a crustose algal-dominated barren instead of simply documenting that a barren had been formed. In both analyses, samples in which there were no algae present were excluded. Samples from the 'after' category were excluded from the second analysis because only 4 quadrats in this category contained algae other than the crustose corallines.

Experimental manipulation of sea urchin densities. We manipulated sea urchin density in cages at Bare Island on an area of reef approximately $400 \mathrm{~m}^{2}$ in size. This reef had not been invaded by high densities of Heliocidaris erythrogramma, and contained the typical foliose algal community for this site. The experiment had 5 treatments: (1) high-urchin density $\left(100 \mathrm{~m}^{-2}\right)$, (2) low urchin density $\left(40 \mathrm{~m}^{-2}\right)$, (3) zero urchin treatment, (4) cage control and (5) open plot. Cages were plasticcoated steel mesh baskets $52 \mathrm{~cm}$ long by $42 \mathrm{~cm}$ wide by $18 \mathrm{~cm}$ high (mesh size $=3 \mathrm{~cm}$ ) bolted to the substratum in an inverted position. Cages for the urchin density treatments and the zero urchin treatment had mesh tops; the cage controls had the mesh tops removed, while the open plots were areas the same size as the 
cage marked with eyebolts at each corner. Cages were attached to the substratum using strips of rubber looped around the corners of each cage and bolted to the substratum with dynabolts. Attaching the cages to the substratum with rubber strips allowed a small amount of movement and reduced the effects of drag by waves, but did not allow enough movement for urchins to escape. There were 8 replicates per treatment.

The 2 experimental densities of Heliocidaris erythrogramma were higher than the densities of adjacent uninvaded areas at Bare Island and both can persist for long periods of time (Wright \& Steinberg 2001, also see results). Hence, our experimental densities reflect invasion into the foliose algal community by 2 unusually high, albeit naturally-occurring, densities of H. erythrogramma (Wright et al. 2000, Wright \& Steinberg 2001). To stock the 2 sea urchin density treatments, $H$. erythrogramma (test diameter 50 to $70 \mathrm{~mm}$ ) were collected by carefully removing them from the substratum to avoid damage, and immediately placed into cages at appropriate densities.

The experiment began on February 27, 1998 and lasted for $208 \mathrm{~d}$. At time zero, we counted the cover of each foliose algal species, crustose algae and bare substratum in each replicate using a 120-point grid on the mesh top of each cage. The 120-point grid excluded the points around the cage perimeter. For the 2 treatments without mesh tops (cage controls and open plots), identical cages were temporarily placed over plots so cover could be measured. We determined the total cover of algae and bare substratum in each cage approximately every $2 \mathrm{wk}$ for $2 \mathrm{mo}$, and then approximately every 4 to 6 wk after that. During sampling, we also counted the number of sea urchins in each cage and added more when required. Points that fell over sea urchins were not counted but this was uncommon as most sea urchins were around the perimeter of the cages during the day.

We used both univariate and multivariate analyses to examine the effects of the 2 high densities of Heliocidaris erythrogramma on algal community structure. Analysis of variance (ANOVA) was used to determine whether the cover of the 6 most abundant foliose algal species (which comprised approximately $95 \%$ of total foliose algal cover), crustose algae and bare substratum differed among treatments at 4 sampling times: 0, 33, 92 and $159 \mathrm{~d}$. Because we sampled the same quadrats at 4 different times, we corrected for multiple comparisons and tested at a significance level of 0.0125 in these analyses. Following ANOVA, we made comparisons between treatments using Tukey's tests. To gain further insight into the survival of foliose algae under intense sea urchin grazing, we determined whether there was a difference in the decline of the 6 most abundant foliose algae in both urchin density treatments. To make these comparisons, we first calculated the mean percentage cover of those 6 species in the high urchin density, low urchin density and zero urchin treatments for each time as a function of the mean percentage cover of that species at time zero. Then, using these standardised (for initial cover) values, we calculated the mean percentage cover of the 6 species in the high and low urchin density treatments, each time as a function of the mean percentage cover of those same species in the zero urchin treatment. We then calculated the slope of the relationship between time and percentage cover (relative to zero urchin treatment) for each species in the 2 sea urchin treatments. Differences among slopes of the 6 species within each sea urchin density category and, between the 2 sea urchin density treatments within species, were examined separately using analysis of covariance (ANCOVA; Quinn \& Keough 2002). The significance of these ANCOVAs was tested after correcting for multiple comparisons.

Temporal change in the composition of the algal community within each treatment was examined using nMDS. For each sampling time, the algal composition was contrasted across treatments using ANOSIM in 2 different ways. First, using all foliose algal species and crustose algae and then, with crustose algae excluded. The significance level of the pairwise comparisons within ANOSIM was corrected for multiple comparisons.

Statistical analyses. Univariate analyses were carried out using SYSTAT (Version 10, SPSS). The assumptions of normality and heterogeneity of variance were checked using frequency histograms of residuals and plots of residuals versus means, respectively (Quinn \& Keough 2002). Logarithmic transformations were made where appropriate. Multivariate scaling and ANOSIM were conducted using Primer (Version 5.2.2, Primer-E). The significance level was taken as $\mathrm{p}<0.05$ except where stated.

\section{RESULTS}

\section{Sea urchin movement and changes in the algal community}

The front of Heliocidaris erythrogramma moved across the substratum in densities greater than $100 \mathrm{~m}^{-2}$ (maximum density: $192 \mathrm{~m}^{-2}$ ). Initially (December 1996), there was a transition along transects from low $\left(<10 \mathrm{~m}^{-2}\right)$ to high $\left(>80 \mathrm{~m}^{-2}\right)$ average densities. However, this transition changed as the urchin front became diffuse. This scattering of urchins was emphasised by similar average densities of sea urchins in quadrats across transects in September 1997 (Fig. 1). 

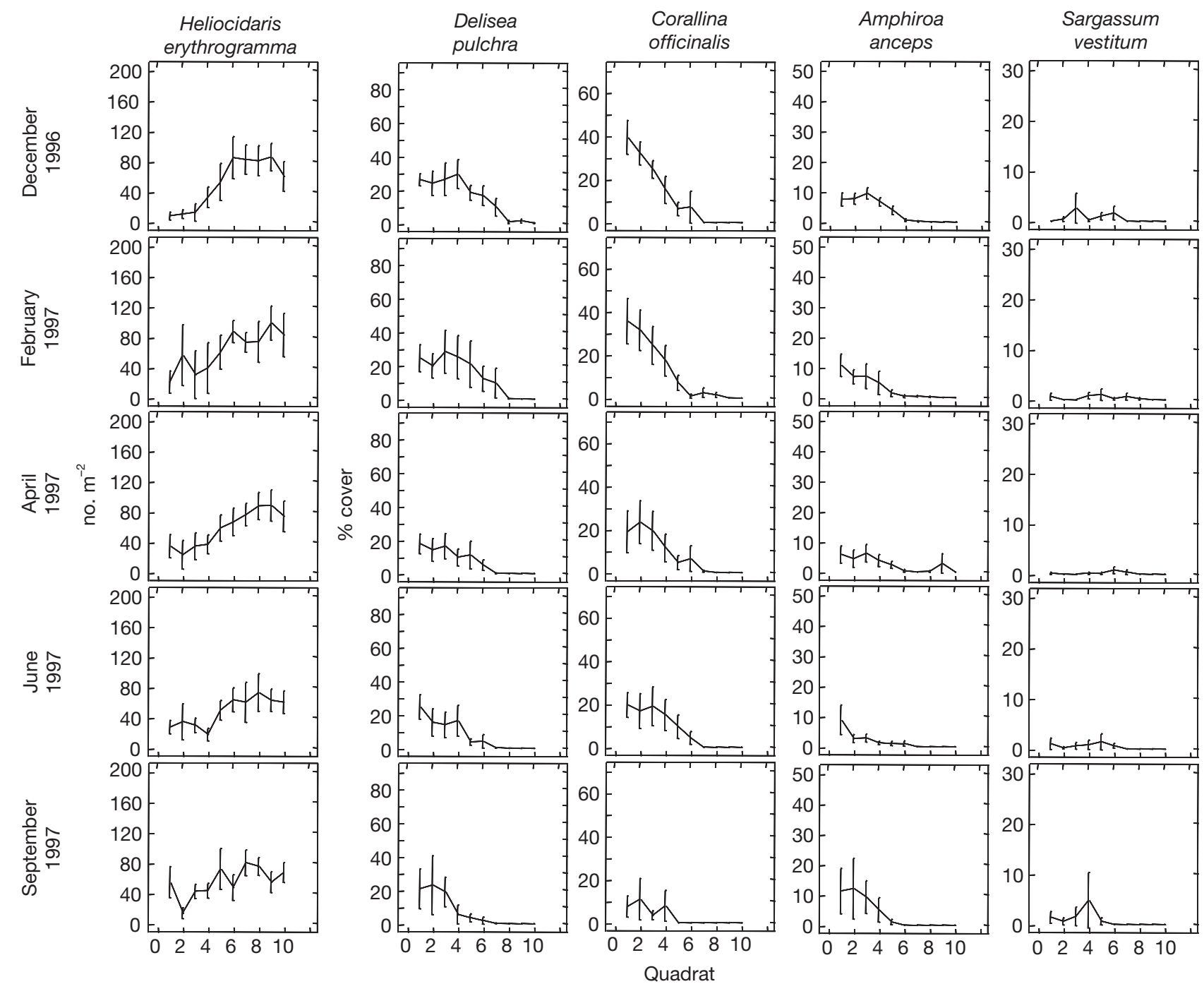

Fig. 1. Mean $( \pm 1 \mathrm{SE})$ densities of Heliocidaris erythrogramma and the percentage cover of foliose algal species, total crustose algae and bare substratum in the permanent quadrats at 5 times. The number of quadrats in each category based on grazing history ('before', 'during' and 'after' grazing) each time was: December 1996 (21, 28, 2); February 1997 (15, 37,1$)$; April 1997 (14, 35, 3); June $1997(13,32,7)$; September $1997(6,35,10)$. Note the variable scale on the $y$-axes

Additionally, in quadrats 1 to 4 , average $H$. erythrogramma densities generally remained between 20 and $40 \mathrm{~m}^{-2}$ from February to September 1997, considerably lower than the very high densities $\left(>80 \mathrm{~m}^{-2}\right)$ that occur at the urchin front.

Each sampling time, quadrats with high densities of Heliocidaris erythrogramma had low cover of all algae except crustose algae (Fig. 1). Generally, with low densities of urchins, there was a relatively high cover of Delisea pulchra, Corallina officinalis and Amphiroa anceps. Other foliose algal species including Sargassum vestitum, Sargassum linearifolium, Ecklonia radiata and Zonaria diesingiana were also present with low densities of urchins but in lower abundance. D. pulchra, and to a lesser extent $C$. officinalis, maintained low cover in quadrats 6 to 8 , which had mean \pm
SE $H$. erythrogramma densities between $60.0 \pm 7.0$ and $87.2 \pm 3.9 \mathrm{~m}^{-2}$ throughout our sampling (Fig. 1). All other foliose algae were in very low abundance, or were completely absent at these sea urchin densities. The cover of crustose algae and bare substratum increased with sea urchin density and both covered approximately $50 \%$ of the substratum at high densities of sea urchins.

When we separated the abundance of each algal species into the 3 sea urchin grazing categories, the role of high densities of sea urchins in removing all foliose algae was emphasised. With the exception of the rare Sargassum vestitum, all non-crustose species had a much lower cover in the 'during' and 'after' categories compared to the 'before' category (Fig. 2). In contrast, crustose algae and bare substratum had high 


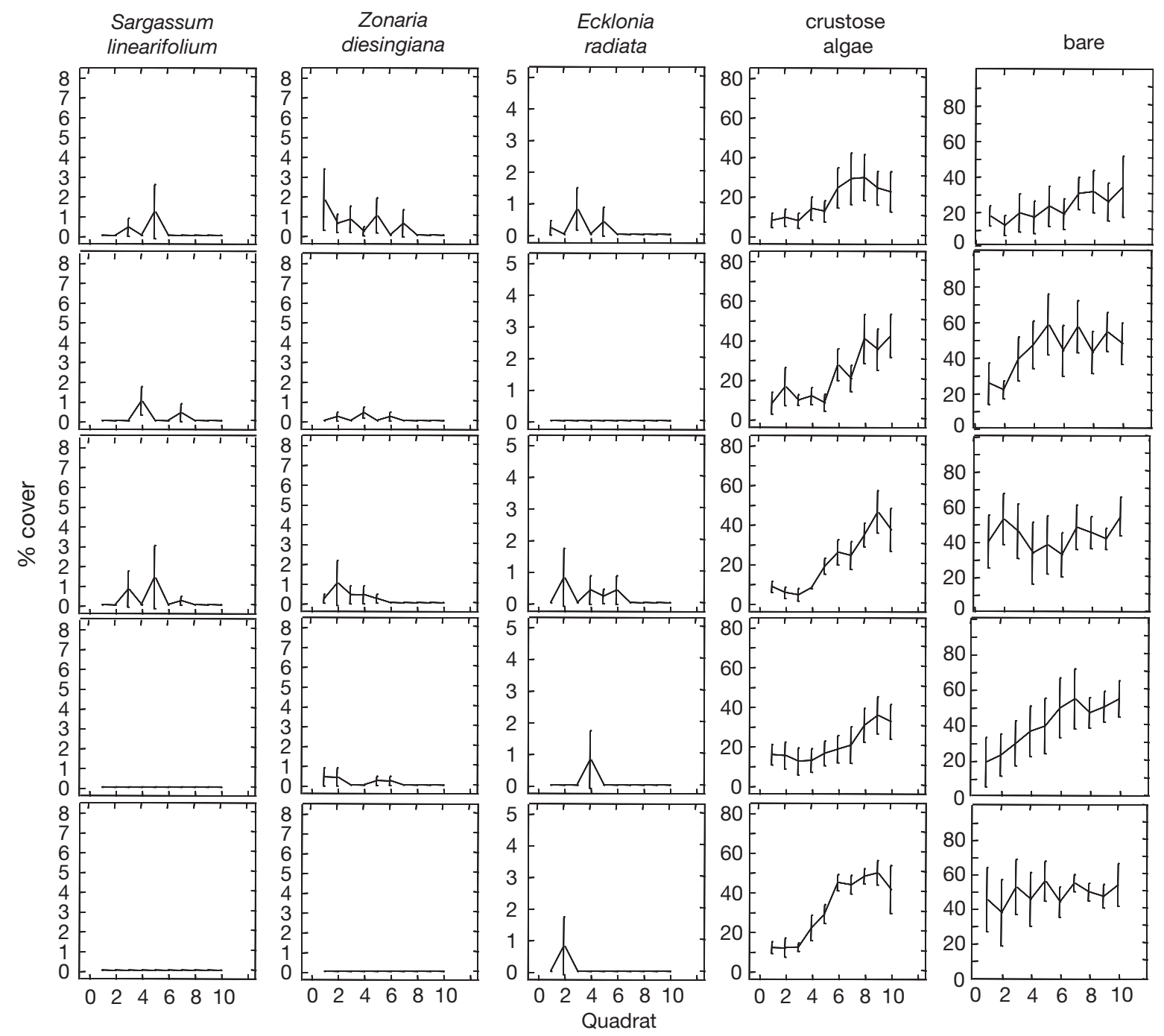

Fig. 1 (continued)

average cover in the 'during' and 'after' categories. The composition of the algal community varied strongly among samples in the 'before', 'during' and 'after' categories (Fig. 3A; ANOSIM contrasting 'before', 'during' and 'after': $R=0.514, \mathrm{p}<0.001$; all pairwise comparisons between 'before', 'during' and 'after' were significant: $\mathrm{p}<0.001$ ). The changes in the composition of the algal community during the formation of the urchin barrens were not, however, simply due to the declining cover of foliose algae and increasing cover of crustose algae. The composition of foliose algae when considered on their own contrasted strongly between samples 'before' and 'during' grazing by high urchin densities (Fig. 3B, ANOSIM, $R=$ $0.22, \mathrm{p}<0.001)$. Over the 5 sampling times, quadrats were in the 'before' category for $1.36 \pm 0.52$ of the time, the 'during' category for $3.2 \pm 0.24$ of the time and the 'after' category for $0.44 \pm 0.12$ of the time $(n=50$ quadrats; mean $\pm \mathrm{SE})$.

\section{Experimental manipulation of sea urchin densities}

With the exception of an initial period (up to Day 14), when some Heliocidaris erythrogramma escaped from cages, and August when there was a mass mortality of sea urchins after an influx of fresh water at our site following heavy rain, the cages maintained the 2 densities of urchins in the treatments (Fig. 4). In addition, only 3 urchins in total were ever observed in control quadrats during the experiment. Following the mass mortality ( $>88 \%$ ) of urchins at the end of August, there was a period of $3 \mathrm{wk}$ when we were unable to gain access to our site and consequently, cages were not restocked until September 18 (Day 204). However, these urchins used to re-stock cages appeared unhealthy and had poor survivorship, hence the experiment was stopped on September 22 (Day 208). Because of the potential artefacts after the mass mortality, we have only analysed data up to Day 159, the sampling time 

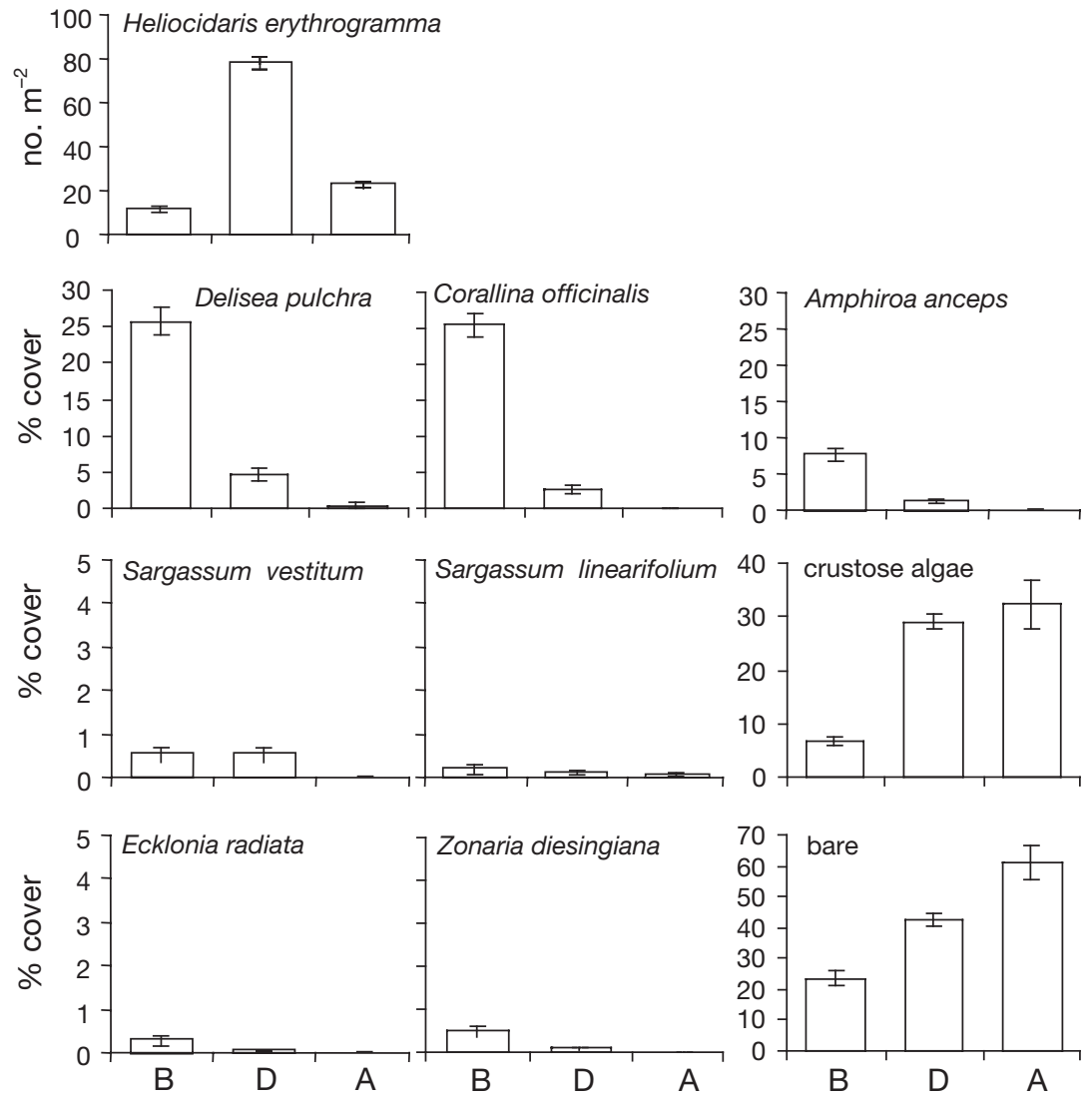

Fig. 2. Mean $( \pm 1 \mathrm{SE})$ densities of Heliocidaris erythrogramma and the percentage cover of foliose algal species, total crustose algae and bare substratum in quadrats for the 3 sea urchin grazing categories 'before' $\left(B_{i} n=69\right)$, 'during' ( $\mathrm{D} ; \mathrm{n}=167)$ and 'after' $(\mathrm{A} ; \mathrm{n}=23)$ grazing

immediately prior to that event, although we have presented plots of percentage cover and MDS ordinations up to Day 208.

Grazing by high densities of Heliocidaris erythrogramma caused a decline in the abundance of all foliose algae. By Day 33, there was a significantly lower
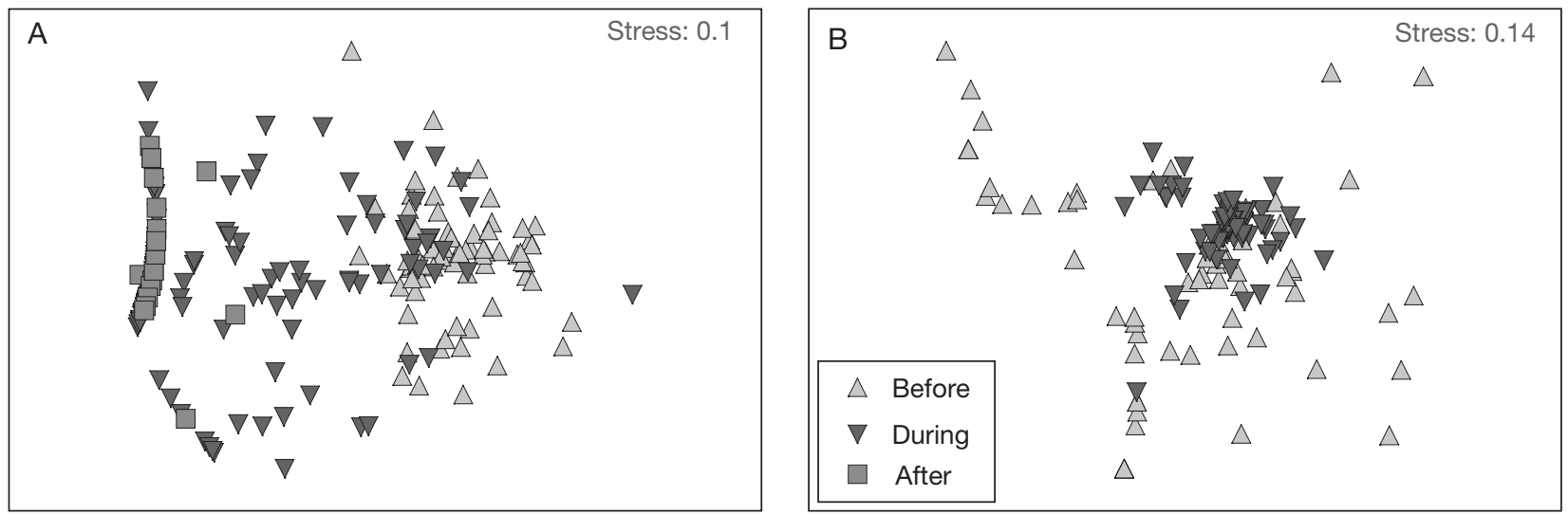

cover of Amphiroa anceps and Zonaria diesingiana in the high-density treatment (Fig. 5). By Day 92, there was also a significantly lower cover of Corallina officinalis in the high-density treatment. Moreover, the mean \pm SE total cover of foliose algae in the high-density treatment declined from a cover of $64.59 \pm$ 3.71 (initially) to $19.13 \pm 2.53 \%$ (Day 92) and, with the exception of Delisea pulchra, the cover of individual species was $<3.5 \%$. By Day 130, the total cover of foliose algae in the high-density treatment was $5.88 \pm 1.41 \%$ and all foliose species remained in very low cover in that treatment until the end of the experiment. Despite such low cover, there were significant differences between the high-density and zero urchin treatment at Day 159 for A. anceps and Sargassum vestitum only. In the low-density treatment, there was a significantly lower cover of A. anceps (Days 33, 92 and 159) and $Z$. diesingiana (Day 33, although for Day $92 \mathrm{p}=0.06$ ) compared to the zero urchin treatment (Fig. 5). There were no differences in the cover of crustose coralline algae between the zero urchin treatment and both urchin density treatments throughout the experiment but there was a significantly higher cover of bare substratum in the high-density treatment versus the zero urchin treatment at Days 33 and 159, and in the low-density treatment versus the zero urchin treatment at Day 159. The cover of D. pulchra and Sargassum linearifolium did not differ between the zero urchin treatment and either urchin density treatment for any dates despite $S$. linearifolium

Fig. 3. MDS plots of algal community composition in quadrats for the 3 sea urchin grazing categories 'before', 'during' and 'after'

grazing. (A) All algae. (B) Foliose algae only. No 'after' data was included in the analysis of foliose algae only
grig. 


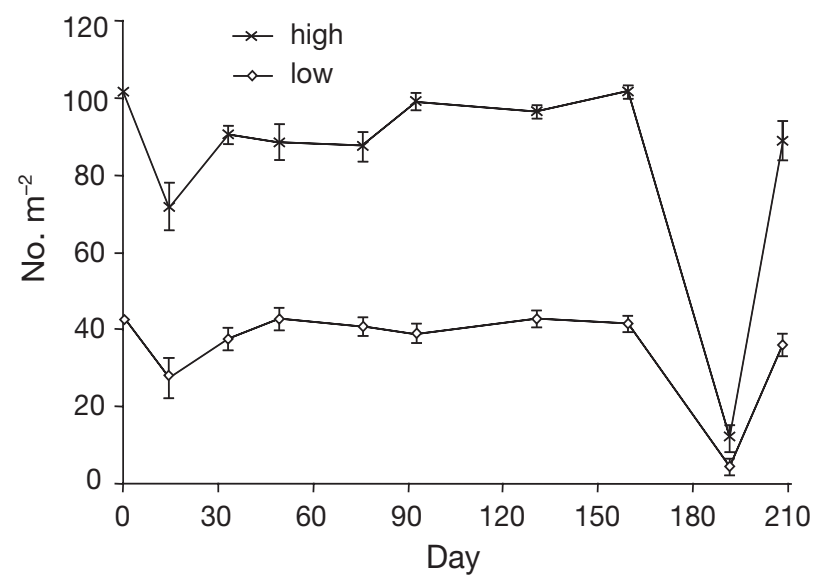

Fig. 4. Heliocidaris erythrogramma. Mean ( $\pm 1 \mathrm{SE})$ abundance in the experimental high and low sea urchin density treatments. The cover of algae was determined on the same days except for Day 191 being at $<0.13 \%$ cover from Day 130. Three other foliose algae occurred in plots during the experiment; Ecklonia radiata, Dilophus marginatus and Wrangelia plumosa. However, both E. radiata and D. marginatus were always in very low cover (0 to $5 \%$ ), while $W$. plumosa only occurred briefly from Days 0 to 49 as an epiphyte. The cover of these 3 species did not differ among treatments at any time. There were 2 occasions when caging artefacts were apparent for individual species; for $A$. anceps (Day 92) and $S$. linearifolium (Day 159), there were differences in the cover in the open plots versus the zero urchin treatment.

ANCOVA revealed no difference in regression slopes among species for either urchin density treatment $\left(F_{5,36}=1.448, \mathrm{p}=0.231\right.$ for high; $F_{5,36}=0.953$, $\mathrm{p}=0.459$ for low). The relative cover of foliose algal species at Day 159 was greater in the low-density treatment compared to the high-density treatment
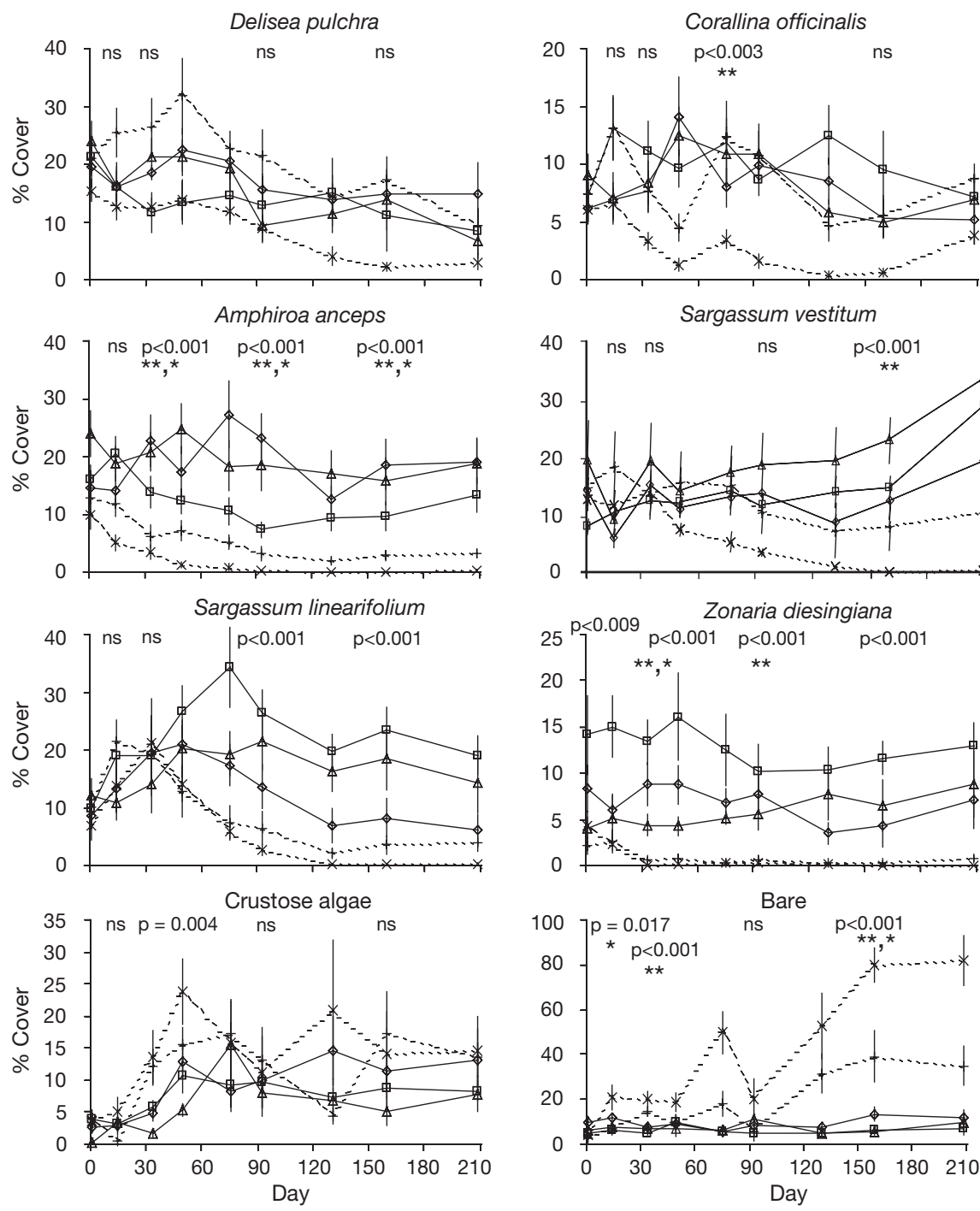
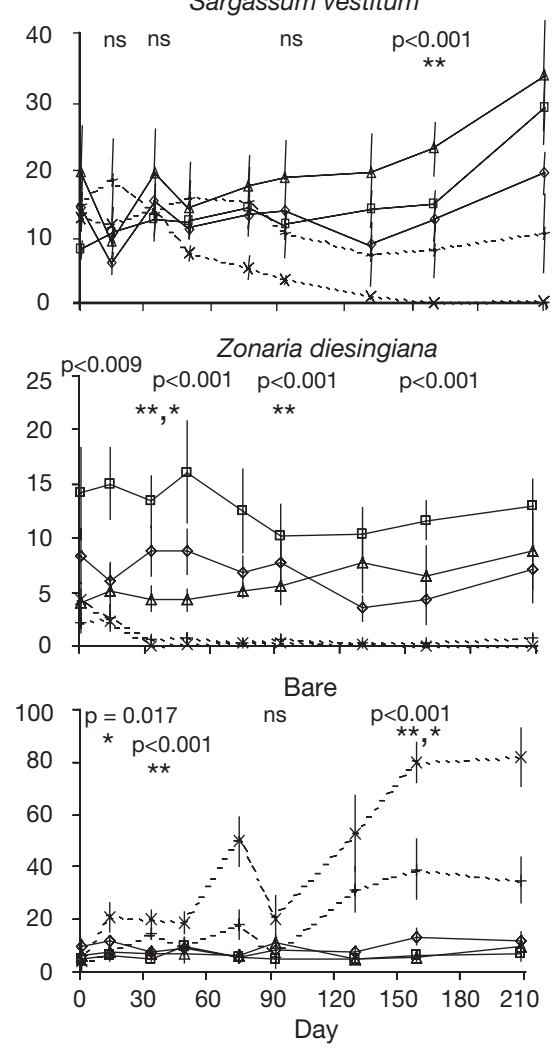

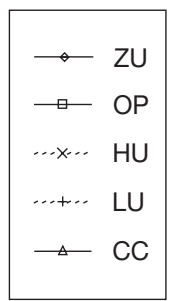

Fig. 5. Mean ( \pm 1 SE) percentage cover of all foliose algal species, total crustose algae and bare substratum in the 5 treatments from the sea urchin density experiment. $\mathrm{P}$ values above Days 0, 33, 92 and 159 are from ANOVAs done on those times with $F_{4,35}$ for all analyses. ns: no significant difference among treatments; **: significant differences between zero and high sea urchin density treatments; *: significant differences between zero and low sea urchin density treatments $(p<0.05$; Tukey's tests). HU: high sea urchin density; LU: low sea urchin density; ZU: zero urchin treatment; CC: cage control; OP: open plot 

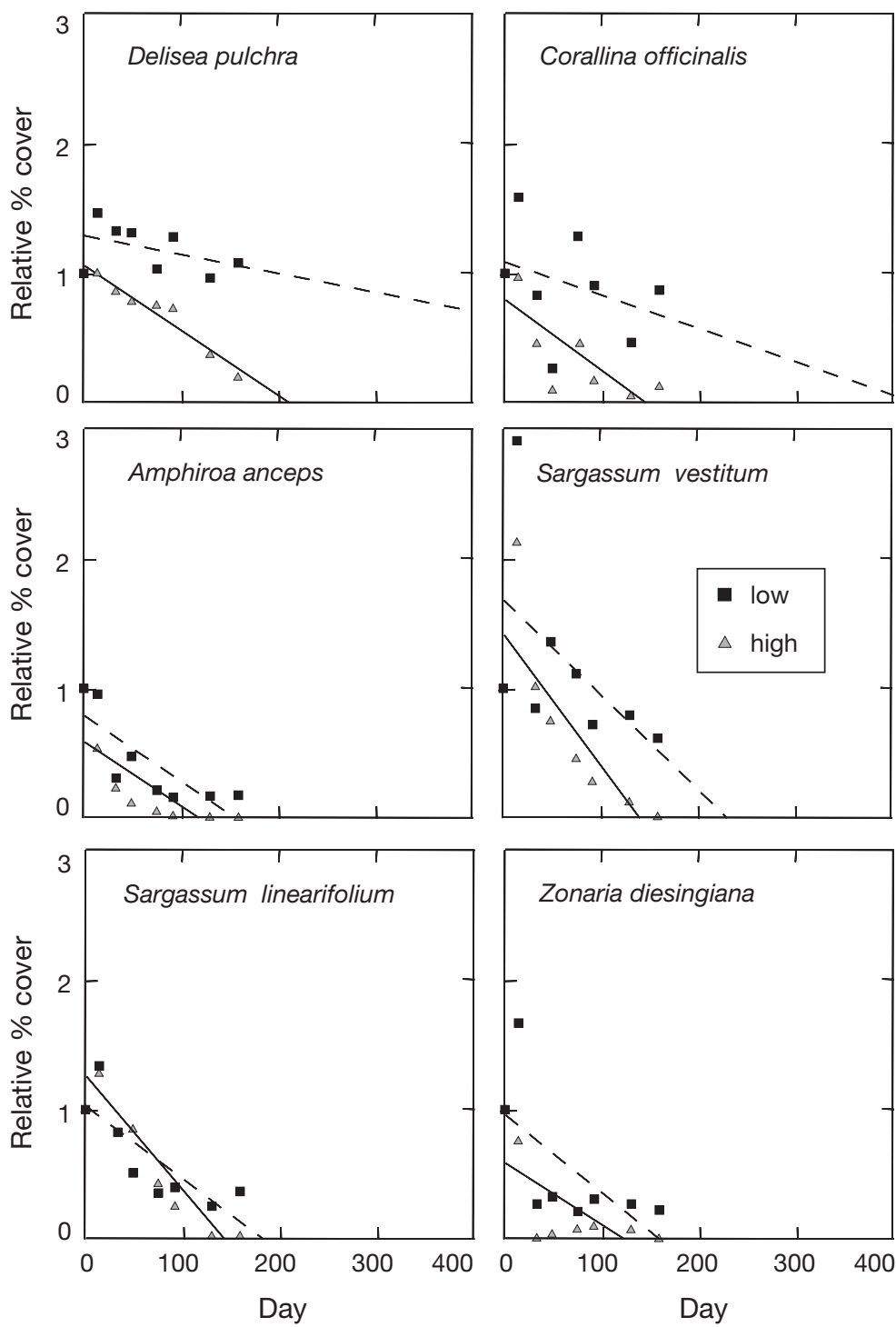

Fig. 6. Decline in the mean percentage cover of the 6 most abundant foliose algae under low (- - ) and high (_- ) sea urchin densities relative to their percentage cover in the zero urchin treatments

( $t$-test comparing high versus low density treatments: $t$ $=3.273, \mathrm{df}=10, \mathrm{p}=0.008)$. The hierarchy of species decline was similar for both densities with Delisea pulchra predicted to reach $0 \%$ cover (the $x$-intercept of the lines of best fit) last at both densities (Fig. 6). D. pulchra was the only species for which there was a difference in regression slopes between the high and low urchin density treatments $\left(F_{1,12}=13.833, \mathrm{p}=\right.$ $0.003)$. To examine whether initial cover of species was important in its relative decline, correlations were performed at both sea urchin densities between the average initial cover and the estimated time to removal (the $x$-intercept of the lines of best fit, Fig. 6) of each species. There were positive but non-significant correlations at both densities (low-density treatment: $\mathrm{r}=$
0.656, $\mathrm{p}=0.157$; high-density treatment: $\mathrm{r}=$ $0.701, p=0.121$ ).

Multidimensional scaling done with all species demonstrated a rapid change in the algal community composition with urchin grazing (Fig. 7A). There were no differences in community composition among highdensity, low-density and zero urchin treatments at 0 and $14 \mathrm{~d}$, but by Day 33, both sea urchin density treatments were significantly different to the zero urchin treatment (Table 1). Moreover, with the exception of Days 92 and 159 (for the low density treatment), sea urchin density treatments differed to zero urchin treatments for all other times. There was only 1 occasion (Day 33) when both sea urchin density treatments did not differ to cage controls and open plots as well. There were also differences between high and low density treatments for Days 75, 130 and 159 (Table 1), indicating density-dependent effects of grazing on the algal community composition. These effects were not only due to the decline in foliose algae and an increase in the relative cover of crustose algae as the area progressed toward a crustose-dominated barren. Similar changes in composition were evident when only foliose algae were included in the analyses (Fig. 7B, Table 2). Differences in foliose algal community composition between the high-density and the zero urchin treatment occurred by Day 33 and between the low-density and zero urchin treatment occurred by Day 49. These differences remained throughout the experiment with the exception of Day 159 when low-density and zero urchin treatments did not differ. Differences in the foliose algal community composition between high and low density treatments occurred for Days 75, 92 and 159 (Table 2). The only differences in foliose algal community composition among the 3 control treatments for both analyses, indicating caging artefacts, occurred between the zero urchin treatment and the open plots for Days 14 and 159 (Table 2).

\section{DISCUSSION}

Many sea urchin species trigger a switch in temperate subtidal communities from a foliose algal- to a crustose algal-dominated state (Dean et al. 1984, Ebeling et al. 1985, Fletcher 1987, Andrew 1993, Leinaas \& Christie 1996, Benedetti-Cecchi et al. 1998, Shears \& 

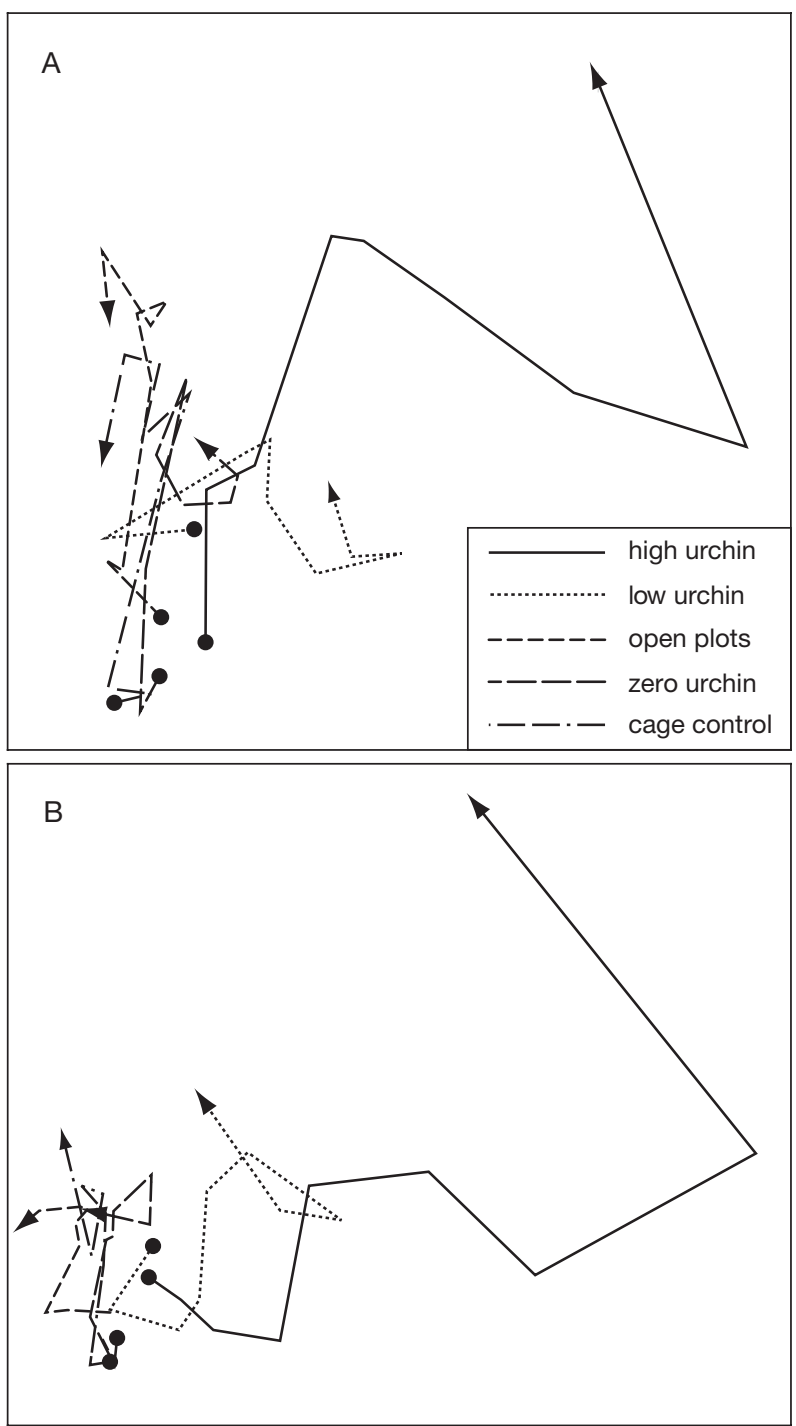

Fig. 7. MDS ordination of each treatment in the sea urchin density experiment (stress $=0.18$ ) for $(\mathrm{A})$ all algae and $(\mathrm{B})$ foliose algae only. Lines connect the centroids of all replicate quadrats within each treatment at each sampling time, starting at the beginning of the experiment (circles) and ending at Day 208 (arrows)

Babcock 2002, Konar \& Estes 2003). As expected, grazing by high densities of Heliocidaris erythrogramma caused such a switch in this community. More specifically, this community went from being dominated by a mix of foliose algae before grazing, through an intermediate state incorporating some of these foliose algae (particularly Delisea pulchra) and crustose algae, and finally to a state containing almost entirely crustose algae. The time for the transition from a foliose algalto a crustose algal-dominated community was relatively quick; within $130 \mathrm{~d}$, grazing by high densities of $H$. erythrogramma caused a decline in the total cover of foliose algae from 64.58 to 5.88 \% (also see Konar \&
Estes 2003). We have also demonstrated that the foliose algal community composition is different in areas grazed by sea urchins compared to ungrazed areas, indicating the differential removal of foliose algae by high densities of sea urchins during grazing. Different densities of sea urchins also resulted in different foliose algal community composition, indicating that if low sea urchin densities persist, then an intermediate state composed of less palatable foliose algae (e.g. D. pulchra) and crustose algae can occur.

\section{Differential removal of foliose algae}

Under intense sea urchin grazing, some foliose algae were removed before others. Amphiroa anceps and Zonaria diesingiana, in particular, were quickly removed and within $33 \mathrm{~d}$, both occurred in lower abundance with high and low urchin densities compared to ungrazed areas. This contrasted to Delisea pulchra and Corallina officinalis, and to a lesser extent both Sargassum species, particularly in the low urchin density treatment. Laboratory consumption rates on these foliose algae by Heliocidaris erythrogramma do not fully explain the differences in persistence observed in the field. In no-choice experiments, D. pulchra was consumed at a low rate compared to C. officinalis and at a similar rate compared to $Z$. diesingiana and Sargassum vestitum (Wright et al. 2004). These inconsistencies suggest that for a variety of reasons, results from feeding experiments with sea urchins may not always reflect patterns of consumption in the field (also see Hill et al. 2003). For example, $C$. officinalis may be more vulnerable to grazing in the laboratory versus the field if small unattached pieces used in laboratory feeding experiments are more susceptible to grazing than attached thalli.

Differential consumption of algal species by sea urchins is usually linked to differences in defensive traits among species, particularly differences in chemical defences (Steinberg 1992, Paul et al. 2001). Delisea pulchra is defended against feeding by Heliocidaris erythrogramma and other macrograzers by non-polar secondary metabolites (halogenated furanones; Wright et al. 2004), and this may be an important reason for the resistance of $D$. pulchra to grazing. We have not examined the effects of the chemical defences of other foliose algae from this community against $H$. erythrogramma, but other sea urchins in this region also consume D. pulchra at low levels relative to brown algae, and are strongly deterred by halogenated furanones, but weakly deterred by brown algal phlorotannins (Steinberg \& van Altena 1992, Williamson et al. 2004, Wright et al. 2004, P. D. Steinberg \& R. de Nys unpubl. data). The removal of Zonaria diesingiana, 
Table 1. Results of ANOSIM comparing algal community composition (all species) during the sea urchin density experiment. Treatments: HU: high sea urchin density; LU: low sea urchin density; ZU: zero urchin treatment; CC: cage control; OP: open plot. The level of significance was set at $p=0.005 .{ }^{*} p<0.005$; ns: non-significant

\begin{tabular}{|c|c|c|c|c|c|c|c|c|}
\hline & \multicolumn{8}{|c|}{ Day } \\
\hline & 0 & 14 & 33 & 49 & 75 & 92 & 130 & 159 \\
\hline Global $R$ & 0.099 & 0.173 & 0.263 & 0.384 & 0.382 & 0.303 & 0.364 & 0.446 \\
\hline \multicolumn{9}{|l|}{ Comparison } \\
\hline HU vs. LU & ns & $\mathrm{ns}$ & ns & ns & * & ns & * & * \\
\hline HU vs. ZU & ns & ns & * & * & * & * & * & * \\
\hline $\mathrm{HU}$ vs. CC & * & $\mathrm{ns}$ & * & $*$ & * & $*$ & * & * \\
\hline HU vs. OP & ns & * & * & * & * & * & * & * \\
\hline LU vs. ZU & ns & ns & $*$ & * & * & ns & * & $\mathrm{ns}$ \\
\hline LU vs. CC & ns & ns & $*$ & $*$ & * & * & * & ${ }^{*}$ \\
\hline LU vs. OP & ns & $*$ & $\mathrm{~ns}$ & $*$ & * & $*$ & * & $*$ \\
\hline ZU vs. CC & ns & ns & $\mathrm{ns}$ & ns & ns & $\mathrm{ns}$ & ns & ns \\
\hline ZU vs. OP & ns & ns & $\mathrm{ns}$ & ns & ns & $\mathrm{ns}$ & ns & ns \\
\hline CC vs. OP & ns & ns & $\mathrm{ns}$ & ns & ns & ns & $\mathrm{ns}$ & ns \\
\hline
\end{tabular}

Table 2. Results of ANOSIM comparing algal community composition (foliose algae only) during the sea urchin density experiment. Abbreviations and symbols as for Table 1

\begin{tabular}{|c|c|c|c|c|c|c|c|c|}
\hline & \multicolumn{8}{|c|}{ Day } \\
\hline & 0 & 14 & 33 & 49 & 75 & 92 & 130 & 159 \\
\hline Global $R$ & 0.058 & 0.169 & 0.230 & 0.372 & 0.465 & 0.342 & 0.401 & 0.511 \\
\hline \multicolumn{9}{|l|}{ Comparison } \\
\hline HU vs. LU & ns & ns & ns & ns & * & * & ns & * \\
\hline HU vs. ZU & ns & $\mathrm{ns}$ & * & $*$ & * & * & * & * \\
\hline HU vs. CC & ns & ns & $*$ & * & * & * & * & * \\
\hline HU vs. OP & ns & $*$ & $*$ & * & * & * & * & * \\
\hline LU vs. ZU & ns & ns & ns & * & * & * & * & $\mathrm{ns}$ \\
\hline LU vs. CC & ns & $\mathrm{ns}$ & $\mathrm{ns}$ & * & * & * & * & $*$ \\
\hline LU vs. OP & ns & $\mathrm{ns}$ & $\mathrm{ns}$ & $*$ & * & * & $*$ & * \\
\hline ZU vs. CC & ns & ns & $\mathrm{ns}$ & ns & $\mathrm{ns}$ & $\mathrm{ns}$ & ns & ns \\
\hline ZU vs. OP & ns & * & $\mathrm{ns}$ & ns & ns & ns & ns & * \\
\hline CC vs. OP & ns & $\mathrm{ns}$ & $\mathrm{ns}$ & ns & ns & $\mathrm{ns}$ & $\mathrm{ns}$ & ns \\
\hline
\end{tabular}

Sargassum vestitum and Sargassum linearifolium, which all contain phlorotannins, by $H$. erythrogramma suggests phlorotannins may be a weak deterrent to $H$. erythrogramma. In general, non-polar compounds such as furanones or terpenes appear to be more deterrent than phlorotannins to sea urchins in Australia (Steinberg \& van Altena 1992) even though phlorotannins are deterrent to urchins in other temperate regions (Steinberg 1992).

The persistence of Delisea pulchra in the low urchin density treatment indicates that non-polar secondary metabolites may play an important community role and allow unpalatable species to persist under sea urchin grazing. Important roles have been described for chemical defences in the persistence of foliose algae, cyanobacteria and sponges in tropical regions against grazing fishes (Pawlik et al. 1995, Duffy \& Hay 2001, Paul et al. 2001) and in the persistence of sponges in temperate regions against sea urchins (Wright et al. 1997). Although temperate brown algae off North Carolina that are unpalatable to grazing fish are dominant where these fish are common (Miller \& Hay 1996, Duffy \& Hay 2000), this is the first description of a community-structuring role for differential grazing by temperate sea urchins linked to algal chemical defences.

The persistence of Corallina officinalis during urchin grazing raises the possibility that structural defences (calcium carbonate) of foliose algae may also deter grazing by Heliocidaris erythrogramma. However, the early removal of Amphiroa anceps by H. erythrogramma indicates that any effects of calcium carbonate are not consistent across articulated coralline species. Calcium carbonate deters feeding by some marine herbivores (Pennings \& Paul 1992, Schupp \& Paul 1994, Hay et al. 1994), although the sea urchin Diadema antillarum was only partially deterred by calcium carbonate, and deterrence increased when secondary metabolites were also present (Hay et al. 1994). Ultimately in our system, it appears that when urchin densities are very high and persist for long enough, even chemically- and/or physicallydefended foliose algae are removed.

Several other factors unrelated to palatability may have influenced the different rates of removal of foliose algae by Heliocidaris erythrogramma. First, rate of removal may simply have been a function of initial abundance. The non-significant, but positive correlations between initial cover and the estimated time to removal provide some support for that idea. However, the finding that Zonaria diesingiana and Corallina officinalis declined at different rates, particularly at 'low' urchin densities, even though both had low initial cover indicates that other factors are important too. Second, some species may be removed more quickly if they are more easily located than other species, or if they are more vulnerable to a strategically-placed bite (e.g. species with a small holdfast area:thallus size ratio may be more susceptible than a species with a relatively large holdfast area:thallus size ratio). Third, differences among species in the ability to tolerate or recover from grazing because of different life histories may also be important. There appeared to be different growth rates among foliose algae during 
our experiment. For example, in the control treatments, both Sargassum species increased cover by up to 2 to 3 times compared to their initial cover. Similarly, the apparent increase in $C$. officinalis cover between days 159 and 208 in both urchin density treatments following the mass mortality of $H$. erythrogramma, suggests that some small thalli of $C$. officinalis remained after grazing and grew rapidly once grazing pressure was removed. Tropical foliose algae can tolerate intense grazing by fishes and regrow rapidly when grazers are removed (Carpenter 1986, Lewis 1986, Lewis et al. 1987).

\section{Density-dependent effects}

There were important density-dependent effects of grazing by Heliocidaris erythrogramma on this algal community. By the end of our experiment, the areas grazed by 100 urchins $\mathrm{m}^{-2}$ consisted almost entirely of crustose algae and bare substratum whereas the areas grazed by 40 urchins $\mathrm{m}^{-2}$ contained a mix of foliose algae, crustose algae and bare substratum. These effects were reflected in the differences in the community structure between these 2 urchin densities considering all algae, and considering just foliose algae. The latter indicates these effects were not simply due to a decline of foliose algae and an increase in crustose algae. Grazing by different densities of Centrostephanus rodgersii also resulted in different algal composition (Hill et al. 2003).

Because the hierarchy of species removal was similar for the 2 experimental sea urchin densities, differences in community composition between densities on the same dates may be due to similar processes occurring at different rates. However, the difference in the relative decline of Delisea pulchra between high and low urchin densities suggests that a lower density of Heliocidaris erythrogramma does not just mean a slower rate of removal for this species. In fact, a threshold density of $H$. erythrogramma ( 80 urchins $\mathrm{m}^{-2}$; see Wright \& Steinberg 2001) may be required before Delisea pulchra is consumed. Similar threshold densities of $H$. erythrogramma were not apparent in the decline of other foliose algae, although note the variable slopes between relative cover and time for Corallina officinalis (Fig. 6). The mechanisms responsible for this threshold effect for D. pulchra are unclear, but may be related to the strong feeding deterrent effects of furanones (Wright et al. 2004). Similarly, once sea urchins have established a crustose-dominated state, total sea urchin removal may be required for the transition to a foliose algal- dominated state (Benedetti-Cecchi et al. 1998, Hill et al. 2003).

\section{Transitions between alternative community states}

Many temperate subtidal algal communities exist as a mosaic of alternative community states that fluctuate in space and time (Ebeling et al. 1985, Konar \& Estes 2003). Both the survey and experimental components of this study indicated that an intermediate community state occurs in addition to the foliose algal- and crustose algal-dominated states. This intermediate community state consisted of a mix of foliose algae, crustose algae and bare rock, and occurred as a function of both time grazed by sea urchins (the 'during' category) and sea urchin density (high versus low urchin density treatments). Although, for the most part, in experimental cages, this intermediate state persisted from Day 75 to Day 159, even foliose algae more resistant to grazing are predicted to eventually decline to zero cover (i.e. where the line of best fit intercepts the $x$-axis, Fig. 6), suggesting that this intermediate state is transitory. The complete removal of foliose algae observed in most quadrats in the 'after' category supports this notion of a transitory intermediate state.

An intermediate community state may have important consequences following a mass mortality of sea urchins. Trajectories of community succession after disturbance are influenced by a variety of stochastic and deterministic factors including the species composition of a site or adjoining sites, a range of site-specific factors, and recruitment (Dudgeon \& Petraitis 2001, Sousa 2001). Here we did not follow community development after the mass mortality of Heliocidaris erythrogramma. However, because there were differences in the foliose algal composition between grazed and ungrazed areas, and between areas grazed for different times and by different densities of sea urchins, mass mortality of $H$. erythrogramma may result in different foliose algal community composition because of different grazing histories.

Clearly, whether subtidal temperate communities end-up at the crustose- or foliose algal-dominated state depends on both the urchin density and its persistence in time (Ebeling et al. 1985, Fletcher 1987, Andrew 1993, Shears \& Babcock 2002, Konar \& Estes 2003). Sea urchin predators may influence the switching between these alternative community states (e.g. Estes \& Pamisano 1974, Estes \& Duggins 1995). In southeastern Australia, large crustose algal-dominated areas occur on coastal reefs (Andrew \& O'Neill 2000), possibly due to a reduction in predation on herbivorous sea urchins because of a reduction in abundance, or lack, of sea urchin predators (Estes \& Steinberg 1988, Steinberg et al. 1995). Theory predicts that the switch between alternative community states requires not just a restoration of the original conditions, but a catastrophic shift (Scheffer et al. 2001). Mass mortality of sea urchins due 
to factors such as storms, reduced salinity or pathogens (Ebeling et al. 1985, Scheibling 1986, Andrew 1991, Scheibling \& Hennigar 1997) may enable such a catastrophic shift to occur and allow southeast Australian reef communities to switch from a crustose-dominated state back to a foliose algal-dominated state.

Acknowledgements. J.T.W, S.A.D, C.N.R, J.E.W. and A.G.B.P. were supported by A. P. A. post-graduate research scholarships. The Australian Research Council and the Centre for Marine Biofouling and Bio-Innovation provided further financial support.

\section{LITERATURE CITED}

Andrew NL (1991) Changes in subtidal habitat following mass mortality of sea urchins in Botany Bay, New South Wales. Aust J Ecol 16:353-362

Andrew NL (1993) Spatial heterogeneity, sea urchin grazing, and habitat structure on reefs in temperate Australia. Ecology 74:292-302

Andrew NL, O'Neill AL (2000) Large-scale patterns in habitat structure on subtidal rocky reefs in New South Wales. Mar Freshw Res 51:255-263

Andrew NL, Underwood AJ (1993) Density-dependent foraging in the sea urchin Centrostephanus rodgersii on shallow subtidal reefs in New South Wales, Australia. Mar Ecol Prog Ser 99:89-98

Benedetti-Cecchi L, Bulleri F, Cinelli F (1998) Density dependent foraging of sea urchins in shallow subtidal reefs on the west coast of Italy (western Mediterranean). Mar Ecol Prog Ser 163:203-211

Bertness MD, Trussell GC, Ewanchuk PJ, Silliman BR, Crain CM (2004) Consumer-controlled community states on Gulf of Maine rocky shores. Ecology 85:1321-1331

Carpenter RC (1986) Partitioning herbivory and its effects on coral reef algal communities. Ecol Monogr 56:345-36

Clarke KR, Warwick RM (1994) Change in marine communities: an approach to statistical analysis and interpretation, 1st edn. Plymouth Marine Laboratory, Plymouth

Dean TA, Schroeter SC, Dixon JD (1984) Effects of grazing by two species of sea urchins (Stronglyocentrotus franciscanus and Lytechinus anamesus) on recruitment and survival of two species of kelp (Macrocystis pyrifera and Pterygophora californica). Mar Biol 78:301-313

Dublin HT, Sinclair AR, McGlade J (1990) Elephants and fire as causes of multiple stable states in the Serengeti-Mara woodlands. J Anim Ecol 59:1147-1164

Dudgeon S, Petraitis PS (2001) Scale-dependent recruitment and divergence of intertidal communities. Ecology 82: 991-1006

Duffy JE, Hay ME (2000) Strong impacts of grazing amphipods on the organization of a benthic community. Ecol Monogr 70:237-263

Duffy JE, Hay ME (2001) The ecology and evolution of marine consumer-prey interactions. In: Bertness MD, Gaines SD, Hay ME (eds) Marine community ecology. Sinauer Associates, Sunderland, MA, p 131-157

Ebeling AW, Laur DR, Rowley RJ (1985) Severe storm disturbances and reversal of community structure in a southern California kelp forest. Mar Biol 84:287-294

Estes JA, Duggins DO (1995) Sea otters and kelp forests in Alaska: generality and variation in a community ecological paradigm. Ecol Monogr 65:75-100
Estes JA, Palmisano JF (1974) Sea otters: their role in structuring nearshore communities. Science 185:1058-1060

Estes JA, Steinberg PD (1988) Predation, herbivory, and kelp evolution. Paleobiology 14:19-36

Fletcher WJ (1987) Interactions among subtidal Australian sea urchins, gastropods, and algae: effects of experimental removals. Ecol Monogr 57:89-109

Gagnon P, Himmelman JH, Johnson LE (2004) Temporal variation in community interfaces: kelp-bed boundary dynamics adjacent to persistent urchin barrens. Mar Biol 144: $1191-1203$

Hay ME (1984) Predictable spatial escapes from herbivory: How do these affect the evolution of herbivore resistance in tropical marine communities? Oecologia 64:396-407

Hay ME, Steinberg PD (1992) The chemical ecology of plantherbivore interactions in marine versus terrestrial communities. In: Rosenthal GA, Berenbaum M (eds) Herbivores: their interaction with plant secondary metabolites. Vol 2: Ecological and evolutionary processes. Academic Press, San Diego, CA, p 371-413

Hay ME, Colburn T, Downing D (1983) Spatial and temporal patterns in herbivory on a Caribbean fringing reef: the effects on plant distribution. Oecologia 58:299-308

Hay ME, Duffy JE, Pfister CA, Fenical W (1987) Chemical defense against different marine herbivores: Are amphipods insect equivalents? Ecology 68:1567-1580

Hay ME, Kappel QE, Fenical W (1994) Synergisms in plant defences against herbivores: interactions of chemistry, calcification, and defence quality. Ecology 75:1714-1726

Hill NA, Blount C, Poore AGB, Worthington D, Steinberg PD (2003) Grazing effects of the sea urchin Centrostephanus rodgersii in two contrasting rocky reef habitats: effects of urchin density and its implications for the fishery. Mar Freshw Res 54:691-700

Hughes TP (1994) Catastrophes, phase shifts, and large-scale degradation of a Caribbean coral reef. Science 256: $1547-1551$

Keesing JK (2001) The ecology of Heliocidaris erythrogramma. In: Lawrence JM (ed), Edible sea urchins: biology and ecology. Elsevier Science, Berlin, p 261-270

Konar B, Estes JA (2003) The stability of boundary regions between kelp beds and deforested areas. Ecology 84: 174-185

Leinaas HP, Christie H (1996) Effects of removing sea urchins (Stronglyocentrotus droebachiensis): stability of the barren state and succession of kelp forest recovery in the east Atlantic. Oecologia 105:524-536

Lewis SM (1986) The role of herbivorous fishes in the organization of a Caribbean reef community. Ecol Monogr 56: $183-200$

Lewis SM, Norris JN, Searles RB (1987) The regulation of morphological plasticity in tropical reef algae by herbivory. Ecology 68:636-641

May RM (1977) Thresholds and breakpoints in ecosystems with a multiplicity of stable states. Nature 269:471-477

Miller MW, Hay ME (1996) Coral/seaweed/grazer/nutrient interactions on temperate reefs. Ecol Monogr 66: 323-344

Paul VJ, Cruz-Rivera E, Thacker RW (2001) Chemical mediation of macroalgal-herbivore interactions: ecological and evolutionary perspectives. In: McClintock JB, Baker BJ (eds) Marine chemical ecology. CRC Press, Boca Raton, FL, p 227-265

Pawlik JR, Chanas B, Toonen RJ, Fenical W (1995) Defenses of Caribbean sponges against predatory reef fish: I. Chemical deterrency. Mar Ecol Prog Ser 127:183-194

Pennings SC, Paul VJ (1992) Effect of plant toughness, calci- 
fication and chemistry on herbivory by Dolabella auricularia. Ecology 73:1606-1619

Quinn GP, Keough MJ (2002) Experimental design and data analysis for biologists. Cambridge University Press, Cambridge

Scheffer M, Carpenter S, Foley, JA, Folke C, Walker B (2001) Catastrophic shifts in ecosystems. Nature 413:591-596

Scheibling RE (1986) Increased macroalgal abundance following mass mortality of sea urchins (Stronglyocentrotus droebachiensis) along the Atlantic coast of Nova Scotia. Oecologia 68:186-198

Scheibling RE, Hennigar AW (1997) Recurrent outbreaks of disease in sea urchins Stronglyocentrotus droebachiensis along the Atlantic coast of Nova Scotia: evidence for a link with large-scale meteorologic and oceanographic events. Mar Ecol Prog Ser 152:155-165

Schrage LJ, Downing JA (2004) Pathways of increased water clarity after fish removal from Ventura Marsh; a shallow, eutrophic wetland. Hydrobiologia 511:215-231

Schupp PJ, Paul VJ (1994) Calcium carbonate and secondary metabolites in tropical seaweeds: variable effects on herbivorous fishes. Ecology 75:1172-1185

Shears NT, Babcock RC (2002) Marine reserves demonstrate top-down control of community structure on temperate reefs. Oecologia 132:131-142

Sousa WP (2001) Natural disturbance and the dynamics of marine benthic communities. In: Bertness MD, Gaines SD, Hay ME (eds) Marine community ecology. Sinauer Associates, Sunderland, MA, p 85-130

Steinberg PD (1992) Geographical variation in the interaction between marine herbivores and brown algal secondary metabolites. In: Paul VJ (ed) Ecological roles for marine

Editorial responsibility: Otto Kinne (Editor-in-Chief), Oldendorf/Luhe, Germany secondary metabolites. Cornell University Press, Ithaca, NY, p 51-92

Steinberg PD, Van Altena I (1992) Tolerance of marine invertebrate herbivores to brown algal phlorotannins in temperate Australasia. Ecol Monogr 62:189-222

Steinberg PD, Estes JA, Winter FC (1995) Evolutionary consequences of food chain length in kelp forest communities. Proc Natl Acad Sci USA 92:8145-8148

Thacker RW, Ginsburg DW, Paul VJ (2001) Effects of herbivore exclusion and nutrient enrichment on coral reef macroalgae and cyanobacteria. Coral Reefs 19:318-329

Van de Koppel J, Rietkerk M, Weissing FJ (1997) Catastrophic vegetation shifts and soil degradation in terrestrial grazing systems. Trends Ecol Evol 12:352-356

Williamson JE, Carson DG, de Nys R, Steinberg PD (2004) Demographic consequences of an ontogenetic shift by a sea urchin in response to host plant chemistry. Ecology 85 : 1355-1371

Wright JT, Steinberg PD (2001) Effects of variable recruitment and post-recruitment herbivory on local population size of a marine alga. Ecology 82:2200-2215

Wright JT, Benkendorff K, Davis AR (1997) Habitat associated differences in temperate sponge assemblages: the importance of chemical defence. J Exp Mar Biol Ecol 213: $199-213$

Wright JT, de Nys R, Steinberg PD (2000) Geographic variation in halogenated furanones from the red alga Delisea pulchra and associated herbivores and epiphytes. Mar Ecol Prog Ser 207:227-241

Wright JT, de Nys R, Poore AGB, Steinberg PD (2004) Chemical defence in a marine alga: heritability and the potential for selection by herbivores. Ecology 85:2946-2959

Submitted: September 14, 2004; Accepted: March 12, 2005 Proofs received from author(s): July 26, 2005 